\title{
METHODOLOGICAL BASIS FOR THE FORMATION OF PUPILS' KNOWLEDGE ABOUT NANOTECHNOLOGY IN THE PROCESS OF TEACHING PHYSICS
}

\author{
Yuliia Tkachenko \\ Postgraduate Student, Sumy State Pedagogical University named after A. S. Makarenko, Ukraine \\ e-mail: julia.tkachenko.0301@gmail.com, orcid.org/0000-0002-2652-2494
}

\section{Summary}

The article is devoted to the analysis of scientific-methodological literature on teaching pupils the elements of nanotechnology and it is found out that the problem of determining the methodological basis for the formation of pupils' knowledge about nanotechnology was not the object of special study. It is determined that the methodological basis for the formation of pupils' knowledge about nanotechnology is a system of methodological approaches. The article highlights and substantiates methodological approaches (competence-based, personality-oriented, activity-based and system), which are used for the formation of pupils' knowledge about nanotechnology in the process of teaching physics. The role of key competencies for studying and understanding nanotechnology by pupils is defined. It is shown that teaching pupils elements of nanotechnology, in turn, contributes to the formation of pupil's key competencies. The conditions and forms of organization of educational activities of pupils in the process of teaching physics for the formation of pupils' knowledge about nanotechnologies are defined. The features of a personality-oriented approach are highlighted, which are fundamental for the formation of pupils' knowledge about nanotechnology. The principles of a system approach are defined, which ensure the creation of an integral methodological system for the formation of pupils' knowledge about nanotechnologies. The article proves that only a complex combination of the analysed methodological approaches will ensure the formation of a complete system of knowledge about nanotechnology in the process of teaching physics.

Keywords: methodology, methodological approach, nanotechnology knowledge, school physics, competency-based approach, personality-oriented approach, activity-based approach, system approach

\section{DOI: https://doi.org/10.23856/3870}

\section{Introduction}

Nanotechnology is a new and promising technology of the XXI century, the basis for the transition of the economy to the sixth technological order. This is why economically and technologically developed countries of the world (the USA, Japan, China, Taiwan, Republic of Korea, Singapore, Finland, Denmark, Germany, France etc.) invest in research and education in the field of nanotechnology. It would seem that the preparation of appropriate personnel support should only affect higher and professional education, but government documents in most countries consider the need to form ideas about nanotechnology among the younger generation at all levels of education. At the same time, one of the basic academic disciplines, given the interdisciplinary nature of nanotechnology, is physics.

On the pages of scientific-methodological publications, scientists cover various aspects of teaching pupils elements of nanotechnologies. Issues of integrating nanotechnology into the content of science curricula are considered by S. Daly, K. Hutchinson, L. Bryan (2007), C. O’connor, H. Hayden (2008), Sh. Y. Stevens, L.M. Sutherland, J.S. Krajcik (2009), 
K. Ban, S. Kocijancic (2011), A. S. Selim, R. A.-H. Al-Tantawi, S. A. Al-Zaini (2015), O. Pasko, O. Avramchuk (2015) etc. The works of Ch. Xie, H.-S. Lee (2012), L. M. Gorghiu, G. Gorghiu (2014), R. L. Olteanu, C. Dumitrescu (2014) are devoted to the use of information and communication technologies in teaching nanotechnologies. Some aspects of teacher preparation for teaching nanotechnology pupils are described in the works of L. Bryan, S. Daly, K. Hutchinson, D. Sederberg, F. Benaissa, N. Giordano (2007), J. Tomasik, S. Jin, R. Hamers, J. Moore (2009) etc. However, in the theory and methodology of teaching physics, there are no studies concerning the methodological basis for the formation of pupils' knowledge about nanotechnology in the learning process.

In the framework of our research, we proceed from the fact that methodology is a system of principles and methods for organizing and building theoretical and practical activities (Konstantinov, 1970). The methodology is based on methodological approaches. The definition of basic methodological approaches to the formation of pupils' knowledge about nanotechnology in the process of teaching physics is the basis for selecting the content, forms, methods and means of teaching.

The purpose of the study: to identify and justify methodological approaches to the formation of pupils' knowledge about nanotechnology in the process of teaching physics.

The analysis of pedagogical-methodological literature has shown a variety of methodological approaches, each of which has its own specifics and performs certain functions. Therefore, in order to distinguish among the existing methodological approaches, those that will contribute to the formation of pupils' knowledge of nanotechnology in the process of teaching physics, we were guided by the following criteria:

- since none of the approaches is universal, it is necessary to build a system of methodological approaches that complement each other;

- the system of methodological approaches should not include conflicting approaches;

- methodological approaches should fully meet the goals and objectives of the methodological system and ensure their achievement and implementation;

- methodological approaches should correspond to the goals and objectives of the subject (Physics) and take into account its features.

Taking into account these criteria, we have identified the following methodological approaches: competence-based, personality-oriented, system, and activity-based.

\section{Competence-based approach}

In the pedagogical literature, the competence-based approach to teaching is positioned as a response to growing concerns about the quality of education. This approach assumes that a school graduate after completing an educational program should not only have a certain amount of knowledge, skills, and abilities, but also have a formed system of competencies (Tkachenko \& Moroz, 2017).

The issue of defining the concepts of "competence", "competence-based approach", classification of competencies, their structure, theoretical-methodological foundations of the implementation of the competence approach in training are disclosed in the works of such scientists as Bekh I. D., Bibik N. M., Jermakov I. Gh., Zymnja I. O., Krajevsjkyj V. V., Kononko O. L., Ljebjedjev O. Je., Lughovyj V. I., Masol L. M., Ovcharuk O. O., Pometun O. I., Savchenko O. Ja., Sukhomlynsjka O. V., Khutorsjkyj A. V.

As it is stated in the National educational Glossary, the competence-based approach is an approach for defining learning outcomes based on their description in terms of competencies (Kremen, 2014). 
In the context of the European Qualifications Framework for Lifelong Learning «competence» means the proven ability to use knowledge, skills and personal, social and/or methodological abilities, in work or study situations and in professional and personal development (European Communities, 2008).

The European Parliament and the Council set out key competencies (European Commission, 2018), the formation of which in pupils will help them not only to find a job, but also to successfully realize themselves in accordance with individual needs and inclinations. Among these key competencies we consider the priority for pupils to understand and study the elements of nanoscience and nanotechnology:

- mathematical competence will allow you to use mathematical methods to study the processes and phenomena of the nanoworld;

- science, technological and engineering competencies will contribute to the understanding of nanotechnologies and their significance for the further development of science;

- digital competence will not only allow you to find, evaluate and use relevant information from nanoscience and nanotechnology, but also facilitate the development and application of information and communication technologies in the study of nanotechnology and their further use;

- personal, social and learning competencies will allow pupils to build their own educational trajectory related to nanoscience;

- entrepreneurship competence will allow future graduates to generate new ideas in the field of nanotechnology and implement them.

The inclusion of nanotechnology elements in the content of the physics training material will also, in turn, contribute to the formation of key competencies (table 1) (Tkachenko, 2018).

Table 1

Subject content of the key competencies and educational resources for their formation

\begin{tabular}{|c|l|}
\hline Key competence & \multicolumn{1}{c|}{ Components } \\
\hline $\begin{array}{c}\text { Communication in } \\
\text { the mother tongue }\end{array}$ & $\begin{array}{l}\text { Skills: to use nanotechnological terms and concepts in speech; clearly and unambig- } \\
\text { uously formulate an answer to a question, justify your own point of view; clearly and } \\
\text { argumentatively express thoughts and conclusions in writing; briefly and competently } \\
\text { pronounce messages, reports, present the results of project activities. } \\
\text { Attitude: to show a value attitude to the scientific Ukrainian language; to critically } \\
\text { evaluate scientific news science in the information space. } \\
\text { Educational resources: textbooks, popular science literature, electronic educational } \\
\text { resources. }\end{array}$ \\
\hline $\begin{array}{c}\text { Communication in } \\
\text { foreign languages }\end{array}$ & $\begin{array}{l}\text { Skills: to read and understand foreign-language educational, popular science literature; } \\
\text { to work with foreign-language electronic educational resources, virtual laboratories. } \\
\text { Attitude: to be aware of the importance of knowledge of international communication } \\
\text { languages for expanding opportunities to obtain information about the development of } \\
\text { modern science and nanoscience in particular. } \\
\text { Educational resources: foreign-language information sources, virtual laboratories. }\end{array}$ \\
\hline Mathematical \\
competence & $\begin{array}{l}\text { Skills: to apply mathematical tools to solve nanotechnological problems, interpret and } \\
\text { evaluate experimental results, to construct and interpret graphs, and diagrams of nano- } \\
\text { material processes. } \\
\text { Attitude: to be aware of the importance of mathematical knowledge for building sci- } \\
\text { entific theories, interpreting research results, and implementing the achievements of } \\
\text { natural science in engineering and technology. } \\
\text { Educational resources: textbooks, collections of problems, popular science literature, } \\
\text { virtual laboratories. }\end{array}$ \\
\hline
\end{tabular}




\section{Table 1 (Continued)}

\begin{tabular}{|c|c|}
\hline $\begin{array}{l}\text { Science, } \\
\text { technological } \\
\text { and engineering } \\
\text { competence }\end{array}$ & $\begin{array}{l}\text { Skills: to explain the processes and phenomena of the nanoworld based on physical, } \\
\text { chemical, and biological knowledge; to understand and explain the structure and prin- } \\
\text { ciple of operation of technical means for the study of objects of the Nanoworld; to } \\
\text { observe, collect data, analyse the results of experiments; to apply knowledge of the } \\
\text { basics of nanotechnology while studying other natural disciplines. } \\
\text { Attitude: to realize the importance of holistic development of the natural sciences to } \\
\text { form a coherent scientific picture of the world and scientific-technical progress; to eval- } \\
\text { uate modern achievements and prospects of development of nanoscience. } \\
\text { Educational resources:popular science literature, electronic educational and informa- } \\
\text { tion resources; virtual laboratories. }\end{array}$ \\
\hline Digital competence & $\begin{array}{l}\text { Skills: to use information-communication systems for searching and processing infor- } \\
\text { mation; to create information products with nanotechnological content; to work with } \\
\text { virtual laboratories, simulation programs. } \\
\text { Attitude: to comply with ethical standards for handling information. } \\
\text { Educational resources: electronic educational and information resources, virtual lab- } \\
\text { oratories. }\end{array}$ \\
\hline $\begin{array}{l}\text { Personal, social } \\
\text { and learning } \\
\text { competencies }\end{array}$ & $\begin{array}{l}\text { Skills: to plan independent study of educational material on the basics of nanotechnol- } \\
\text { ogy; independently search for information, draw conclusions, acquire new knowledge. } \\
\text { Attitude: critically evaluate your own achievements; to realize the importance of } \\
\text { self-education for your own intellectual development. } \\
\text { Educational resources: educational, encyclopaedic and popular science literature, } \\
\text { electronic educational resources. }\end{array}$ \\
\hline $\begin{array}{l}\text { Entrepreneurship } \\
\text { competence }\end{array}$ & $\begin{array}{l}\text { Skills: to work in a team, conduct a dialogue, take initiative, make responsible deci- } \\
\text { sions when performing training tasks and projects; to organize collective work, distrib- } \\
\text { ute functions and responsibilities among group members to complete a training task or } \\
\text { project. } \\
\text { Attitude: to understand responsibility for decision-making; initiative, hard work, } \\
\text { self-confidence. } \\
\text { Educational resources: literature about famous modern scientists whose activities had } \\
\text { a significant impact on the development of the economy, excursions to scientific institu- } \\
\text { tions and modern enterprises. }\end{array}$ \\
\hline Civic competence & $\begin{array}{l}\text { Skills: to argue and defend your own position; to adhere to generally recognized moral } \\
\text { principles and values in the learning process; to resolve conflicts, reach compromises. } \\
\text { Attitude: to evaluate the significance of nanoscience achievements for the social devel- } \\
\text { opment of the Ukrainian state, improving the welfare of its citizens; to accept the views } \\
\text { of others with tolerance. } \\
\text { Educational resources: mass media, educational and social projects. }\end{array}$ \\
\hline $\begin{array}{l}\text { Cultural awareness } \\
\text { and expression } \\
\text { competencies }\end{array}$ & $\begin{array}{l}\text { Skills: to explain and give examples of the relationship between nanotechnology and art. } \\
\text { Attitude: to be aware of the unity of the development process of nanoscience and culture. } \\
\text { Educational resources: works of art, electronic information resources. }\end{array}$ \\
\hline
\end{tabular}

\section{Activity-based approach}

The methodological basis for the development of competence is the activity-based approach, since competence is formed and manifested in the process of activity (Sharko \& Liskovych, 2012).

The activity-based approach is quite common in psychological and pedagogical research (B. Ananjjev, I. Bekh, L. Vyghotsjkyj, P. Ghaljperin, V. Davydov, L. Zajceva, I. Zymnja, N. Kuzjmina, A. Leontjjev, S. Rubinshtejn, V. Slastjonin, O. Shherbakov, E. Judin). Scientists define the essence of the activity-based approach in different ways: as a set of educational technologies or methodological techniques, as a methodological basis for developing learning, as an educational concept that is based on the subject activity of pupil. 
The State standard of basic and complete general secondary education of Ukraine states that the activity-based approach is the orientation of the educational process to the development of skills and abilities of the individual, the practical application of knowledge obtained from various academic subjects, successful adaptation of a person in society, professional self-realization, the formation of abilities for collective activity and self-education (Verkhovna Rada of Ukraine, 2011).

In other words, the essence of the activity-based approach is to direct the educational process towards mastering various types of activities by pupils, in the course of which they acquire knowledge, form skills and apply this knowledge in further education, professional activities and everyday life.

The activity-based approach to the formation of pupils' knowledge about nanotechnology determines the inclusion of pupils in various types of educational activities. The effectiveness of various types of educational activities depends on the special conditions specific to each of its types. For educational activities aimed at developing pupils' knowledge about nanotechnology, these are:

- motivation of educational activity: the content of educational material should be new and interesting; teaching methods should encourage intense mental activity; visual and emotional presentation of educational material, the atmosphere in the classroom, which encourages pupils to learn;

- logical presentation of educational material: taking into account the abilities and inclinations, the level of formation of basic knowledge, skills and abilities; intellectual development of pupils;

- performing exercises for generalization and systematization of educational material, as well as performing exercises for applying knowledge in practice;

- orientation of the learning process to the level of "knowledge-belief";

- formation of pupils' value attitude to the educational material.

The application of the activity-based approach determines the use of various forms of organization of educational activities of pupils. Among the forms of organization of educational activities of pupils in the process of teaching physics for the formation of pupils' knowledge about nanotechnology, priority is given to:

- active and interactive lessons;

- scientific-practical seminars and conferences;

- real and virtual tours;

- scientific and technical exhibitions.

The activity-based approach focuses the organization of the process of formation of pupils' knowledge about nanotechnology on providing an active, personally significant, conscious educational activity of the pupil, the content of which is not so much in the acquisition of certain knowledge, but in the formation of skills to apply this knowledge in practice. This determines the choice of appropriate methods of teaching pupilselements of nanotechnology the project method, interactive methods, methods of problem-finding and research.

The activity-based approach is an alternative to passive learning by pupils and allows them to achieve educational goals that embody the needs of society and the state.

\section{Personality-oriented approach}

The personality-oriented approach is presented in the research of H. O. Ball, I. D. Bekh, Ye. V. Bondarevska, H. P. Vasianovich, E. F. Zieier, O. M. Piekhota, O. Ya. Savchenko, V. V. Sierikov, A. V. Khutorskyi, I. S. Yakymanska. The analysis of scientific-methodological 
literature has shown that there are certain differences in the definition of the essence of the personality-oriented approach by scientists. We have identified the characteristic features of this approach, which are fundamental for the formation of pupils' knowledge about nanotechnology:

- creation of optimum conditions for development and formation of a personality;

- taking into account the individual needs, abilities, aptitudes, value orientations and capabilities of apupil;

- creating opportunities for building an individual educational trajectory of apupil;

- the training material should take into account pupils' subjective experience;

- knowledge formation should be aimed not only at expanding its scope, but also at structuring, integrating, generalizing and applying it in practice;

- orientation on self-development and self-education of apupil;

- interaction between teachers and pupils is based on the principles of cooperation, mutual respect and mutual understanding.

Taking into account the personal-oriented approach in teaching pupils the elements of nanotechnology defines the educational material as an incentive for value-semantic searches of the individual, priority methods of teaching are problem-search, research, and the result is activity, cognitive preferences, and the pupil's personal position.

\section{System approach}

Important for the formation of pupils' knowledge about nanotechnology is a system approach, to which the scientific works of scientists are dedicated: V. Gh. Afanasjjev, I. V. Blaubergh, O. Leontiev, A. Petrovskyi, S. Rubinstein, V. N. Sadovsjkyj, Ju. O. Shabanov, E. Gh. Judin etc. The system approach is used in conjunction with the personality-oriented and activity-oriented approaches, which, according to O. Leontiev (2005), A. Petrovskyi (1981), S. Rubinstein (1989), implies turning to the inner world of the individual and the maximum development of his individual characteristics.

The system approach makes it possible to divide complex phenomena of reality into parts or elements, to determine how to organize individual parts (elements) of the system into a single whole, to replace the order of the system elements and their interaction. It implements in practice the principle of holistic consideration of phenomena in relation to each other (Shabanova, 2014: 29). In accordance with this approach, we consider the method of forming pupils' knowledge about nanotechnologies as an integral system, the components of which are the purpose, content, forms, methods, tools and results of training.

We believe that developing pupils' knowledge about nanotechnology in learning physics should be based on the following principles of system approach:

- general purpose (functioning, development and improvement of the system must subdue to a pre-determined goal);

- integrity (the system is considered as a whole, which has its own specific functions and patterns);

- organization (the system is considered as a set of elements between which connections and dependencies are established);

- functionality (to achieve a common goal, the system performs certain functions);

- dynamism (individual elements of the system, and the system as a whole, are subject to development and improvement);

- uncertainties (random events, unknown external influences, etc.). 
Using system approach for developing in pupils knowledge about nanotechnology in the process of teaching physics will help to develop a holistic methodological system of formation of pupils' knowledge about nanotechnology; to allocate system-forming factor of the methodological system, that is the purpose and result; to construct a system of interrelated elements; to reveal the main conditions of existence of this system.

\section{Conclusions}

The need for propaedeutics of nanotechnology at the school level is currently one of the conditions for the development of the nanotechnology industry in economically and technologically developed countries. However, despite the fact that this problem is in the centre of attention of scientists, there are no studies in the theory and methodology of teaching physics concerning the methodological basis for the formation of pupils' knowledge about nanotechnology in the process of teaching physics. Among the existing methodological approaches and taking into account the criteria, we have identified competence-based, personality-oriented, activity-based and system approaches. Each of these approaches plays an important role in the formation of pupils'knowledge about nanotechnology. It is obvious that their combination in the interconnected system will ensure: the formation of knowledge about nanoobjects, nanomaterials and their properties, and technology of getting nanostructures and nanomaterials, the modern means of thestudy of nanoscale objects, achievements and prospects of application of nanotechnology; skills to apply the knowledge of nanotechnology in everyday life, further training and professional activities; formation of a value attitude to scientific-technical achievements in the field of nanoscience and nanotechnology, understanding the significance of physics in the development of nanotechnology.

We see prospects for further study of the stated problem in the development and justification of an integral methodological system for the formation of pupils' knowledge about nanotechnology in the process of teaching physics.

\section{References}

Ban, K., \& Kocijancic, S. (2011). Introducing topics on nanotechnologies to middle and high school curricula. In 2nd World Conference on Technology and Engineering Education (pp. 78-83). Ljubljana, Slovenia. Retrieved July 23, 2020, from http://www.wiete.com.au/conferences/2wctee/papers/14-06-Ban-K.pdf. [in English]

Bryan, L. A., Daly, S., Hutchinson, K., Sederberg, D., Benaissa, F., Giordano, N. (2007). A designbased approach to the professional development of teachers in nanoscale science. In Annual meeting of the National Association for Research in Science Teaching, Baltimore, MD. [in English]

Daly, S., Hutchinson, K., Bryan, L. (2007). Incorporating nanoscale science and engineering concepts into middle and high school curricula. In Annual Conference of the American Society for Engineering Education. Honolulu, Hawaii. [in English]

European Communities. (2008). The European Qualifications Framework for Lifelong Learning. Luxembourg, Belgium: Office for Official Publications of the European Communities. Retrieved July 18, 2020, from https://www.google.com/url?sa=t\&rct=$j \& q=\&$ esrc $=s \&$ source $=$ web $\& c d=\& v e d=2$ ahUKEwiPy83np_jqAhXImIsKHROQCeAQFjACegQIBRAB\&url=http $\% 3 \mathrm{~A} \% 2 \mathrm{~F} \% 2 \mathrm{Fecompetences.eu \% 2Fwp-content \% 2Fup-}$ loads\%2F2013\%2F11\%2FEQF_broch_2008_en.pdf\&usg=AOvVaw07kGXbFUh5OBJZeL4PIaFM. [in English] 
European Commission. (2018). Commission Staff Working Document Accompanying the document "Proposal for a Council Recommendation on Key Competences for Lifelong Learning". Brussels, SWD. Retrieved July 15, 2020, from https://www.google.com/url? sa=t\&rct=j\&q=\&es$r c=s \&$ source $=$ web $\& c d=\& v e d=2$ ahUKEwi $1 g 8 j E x \_j q A h X h-y o K H V W l D h k Q F j A A$ egQIARAB\&url=https $\% 3 A \% 2 F \% 2 F$ eur-lex.europa.eu $\% 2 F$ legal-content $\% 2 F E N \% 2 F T X T \% 2 F$ PDF\%2F\%3Furi\%3DCELEX\%3A52018SC0014\%26from\%3DEN\&usg=AOvVaw0iNWrpaXX-fq51loOxtgDS. [in English]

Gorghiu, L. M., \& Gorghiu, G. (2014). Teachers' and students' feedback concerning the use of ICT tools in learning science through nanotechnology. Recent Researches in Applied Computers and Computational Science. In 11 th WSEAS International Conference on Applied Computer and Applied Computational Science (pp. 194-199). Wisconsin, USA. [in English]

Gorghiu, L. M., Gorghiu, G., Olteanu, R. L. \& Dumitrescu, C. (2014) Using Various NTSE Virtual Laboratory Resources for Developing the Students' Knowledge Related to Nanoscience and Nanotechnology. Global Journal on Technology, 06, 170-176. [in English]

Konstantinov, F. V. (Ed). (1970). Filosofskaya enciklopediya [Philosophical encyclopedia] (vol. 2). Moscow: Sovetskaya enciklopediya. [in Russian]

Kremen, V. H. (Ed.). (2014). Natsionalnyi osvitnii hlosarii: vyshcha osvita [National educational glossary: Higher education] (2nd ed.). Kyiv: TOV “Vydavnychyi dim "Pleiady". [in Ukrainian]

Leontev, A. N. (2005). Deyatelnost. Soznanie. Lichnost [Activity. Consciousness. Personality]. Moscow: Smysl, Akademiya. [in Russian]

O'Connor, C., \& Hayden, H. (2008). Contextualising Nanotechnology in Chemistry Education. Chemistry Education Research and Practice, 9, 35-42. doi:10.21427/b3jx-3c37. [in English] Pasko, O. O., Avramchuk, O.Ye. (2015). Mistse nanotekhnolohii u navchalnykh prohramakh z fizyky ta standartakh zahalnoi serednoi osvity - perspektyvy rozvytku [The place of nanotechnologies in physics training programs and standard of secondary school and its development prospects]. Bulletin of the T.H. Shevchenko National University "Chernihiv Colehium”, 127, 160-162. Retrieved July 21, 2020, from http://nbuv.gov.ua/UJRN/VchdpuP_2015_127_39. [in Ukrainian]

Petrovskij, A.V. (1981). Lichnost v psihologii s pozicii sistemnogo podhoda [Personality in psychology from the standpoint of a systems approach]. Voprosy Psychologii, 1, 57-66. [in Russian] Rubinshtejn, S. L. (1989). Princip tvorcheskoj samodeyatelnosti. K filosofskim osnovam sovremennoj pedagogiki [The principle of creative amateurism. To the philosophical foundations of modern pedagogy]. Voprosy filosofii, 4, 89-95. [in Russian]

Selim, S. A. S., Al-Tantawi, R. A.-H., Al-Zaini, S. A. (2015). Integrating nanotechnology concepts and its applications into the secondary stage physics curriculum in Egypt. European Scientific Journal, 11(12), 193-212. [in English]

Shabanova, Yu. O. (2014). Systemnyi pidkhid u vyshchii shkoli [System approach in high school]. Dnipropetrovsk: NHU. [in Ukrainian]

Sharko, V. D., Liskovych, O. V. (2012). Formuvannia navchalno-piznavalnoi kompetentnosti uchniv osnovnoi shkoly u protsesi vyvchennia fizyky yak metodychna problema [Formation of learning and cognitive competence pupils of basic school in the process of studying physics as a methodological problem]. Naukoyi Chasopys National Pedagogical Dragomanov University. Series 5. Pedagogical sciences: reality and perspectives, 32, 228-235. Retrieved July 22, 2020, from http://enpuir.npu.edu.ua/bitstream/123456789/4069/1/Sharko\%20\%20 Liskovych. pdf. [in Ukrainian] 
Stevens, Sh. Y., Sutherland, L. M., \& Krajcik, J. S. (2009). The Big Ideas in Nanoscale Science and Engineering: A Guidebook for Secondary Teachers. Arlington: National Science Teachers Association. [in English]

Tkachenko, Yu. A., \& Moroz, I. O. (2017). Kompetentnisnyi pidkhid do vykladannia osnov nanotekhnolohii [Competence-based approach in teaching nanotechnology]. Bulletin of the T.H. Shevchenko National University "Chernihiv Colehium”, 146, 192-195. Retrieved July 22, 2020, from http://nbuv.gov.ua/UJRN/VchdpuP_2017_146_44. [in Ukrainian]

Tkachenko, Yu.A. (2018). Mistse osnov nanotekhnolohii $\bar{u}$ Novii ukrainskii shkoli [The place of basics of nanotechnology in the New Ukrainian School]. In Scientific activity as a way of formation of professional competencies of the future specialist (pp. 122-124). Sumy, Ukraine. Retrieved July 12, 2020, from http://fizmatsspu.sumy.ua/Konferencii/sbor/npk/NPK-2018-1-. pdf. [in Ukrainian]

Tomasik, J., Jin, S., Hamers, R., \& Moore, J. (2009). Design and initial evaluation of an online nanoscience course for teachers. Journal of Nano Education, 1, 48-67. [in English]

Verkhovna Rada of Ukraine. (2011). Derzhavnyi standart bazovoi i povnoi zahalnoi serednoi osvity [State standards for the basic and complete secondary education]. Kyiv, Ukraine. Retrieved July 17, 2020, from https://zakon.rada.gov.ua/laws/show/1392-2011-\%D0\%BF. [in Ukrainian]

Xie, Ch. \& Lee, H.-S. (2012). A Visual Approach to Nanotechnology Education. International Journal of Engineering Education. 28. 1006-1018. [in English] 